\title{
Development of Android-Based Information Systems Faculty of Education
}

\author{
Hendra Dedi Kriswanto \\ Non-formal Education \\ Universitas Negeri Semarang, Indonesia \\ hendra.dedi@mail.unnes.ac.id
}

\author{
Mu'arifuddin \\ Non-formal Education \\ Universitas Negeri Semarang, Indonesia \\ muarifuddin@mail.unnes.ac.id
}

\author{
Dania Ayu Wulandari \\ Faculty of Education \\ Universitas Negeri Semarang, Indonesia \\ daniaayuwulandari@mail.unnes.ac.id
}

\begin{abstract}
Internet usage in Indonesia is increasing. The majority of user's access using Android-based smartphones. This is supported by the number of smartphone users which is expected to continue to increase since 2016. This is the background of researchers in developing Android-based information systems. Based on observations at the Faculty of Education UNNES, information media used include: websites and social media. This study aims to determine: (1) the development of an Android-based information system, and (2) the feasibility of an Android-based information system at the Faculty of Education UNNES. The development model used is Waterfall, namely: communication, planning, modeling, construction, and deployment. Based on the feasibility assessment by the media validator, it shows that the application got a value of $87.5 \%$. This shows Android-based information systems Faculty of Education UNNES very feasible for use in a $p$ OSes dissemination of information.
\end{abstract}

Keywords: android, smartphone, internet, information system

\section{INTRODUCTION}

Internet usage in Indonesia is considered quite high. Indonesia is located on the ranking fifth out of 10 countries with the internet site in the world that is as much as 143.26 million [1]. This internet access is done through a computer or cell phone. The percentage ownership of the computer / laptop reached $25.72 \%$ and smartphone / tablet reached $50.08 \%$ based on the number of populations in Indonesia in the year 2017 [2]. Based on the 2018 survey by APJII that $93.9 \%$ of users access the internet using a personal smartphone / tablet every day.

Number of users of smartphones are already expected to continue to rise since the year 2016 as many as 2.1 billion and in the year 2019 will reach 2.5 billion [3]. It is still expected to continue to increase until 2020. This was supported also that the number users of smartphones participating increased by leaps and bounds with estimates of the Institute for Research Digital Marketing eMarketer, in the year 2018 reached more than 100 million people [4].

System Operating Android is a system operating mobile (smartphone) that most lots are used and in demand users to communicate and seek an update [5]. Then it was reported from tribunjabar.id that Android has controlled more than 90 percent of the smartphone market in Indonesia and 75 percent in the world due to the widespread use of Android in all corners of the world [6]. Android is a system operating based on Linux for devices mobile such as smartphones and tablets that provide a platform open for the developers to create applications that can they develop themselves to be used by various kinds of devices mobile [7].

The Faculty of Education UNNES continues to strive to improve its quality as an educational institution in providing public services including increasing the reach of public information that can be accessed by internet users around the world. These qualities will drive the success and progress of higher education. One form is the improvement of the quality of institutional information systems. System information has the role of disseminating information in an effective and efficient rated of time, cost, and range [8]

The Faculty of Education has a website-based information system with the URL: http://fip.unnes.ac.id. But along with the development of the internet and android this is the background of researchers to optimize access to information systems using the Android operating system with the development of Android -based information systems. This is expected to make it easier for users to access the Education Faculty information system easily and practically.

\section{METHOD}

Research is going to use the methods of research and development, or research and development. Methods of research and development is a method of research that is used to produce a product specific and test the effectiveness of products such [9]. The researcher developed an Android-based information system (FIP Apps) using the waterfall model software development method. Here is the diagram of the waterfall model with 5 stages (Figure 1) according to Pressman [10].

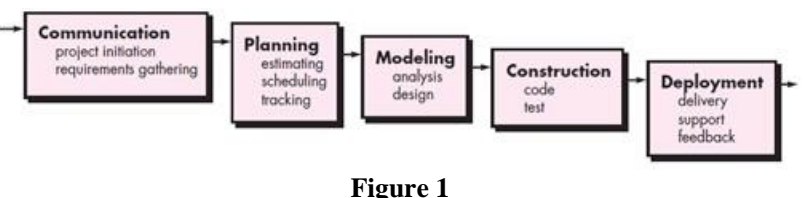

Waterfall Model Software Development 


\section{A. Communication (Project Initiation \& Requirements Gathering) \\ This stage is needed is an analysis of functional and non-functional requirements. Functional needs include the concept of information that will become data / information for the intended use and target characteristics. This is to define each user's needs needed to achieve the expected goals. While non-functional requirements include software requirements specification (software), hardware (hardware), and feasibility analysis.}

\section{B. Planning (Estimating, Scheduling, Tracking)}

This stage is in the form of estimating, scheduling using a project plan, and tracking the process of working on the system.

\section{Modelling (Analysis \& Design)}

The stage in the form of designing an Androidbased information system related to media format and application design. The choice of media format the researcher determines on the Android Application. The initial design includes: flowchart, navigation flow and the creation of a storyboard that contains visual columns and material which is a complete application design used as a reference for the development of information systems. Navigation flow is a structural design or flow of a program that describes the construction between sections [11]. While the storyboard is a narrative and visual that illustrates the sequence of components in the media [12]. The following will be presented in the form of a hierarchical / branched navigation structure with the main menu display form as the main page by having a branching page (Figure 2).

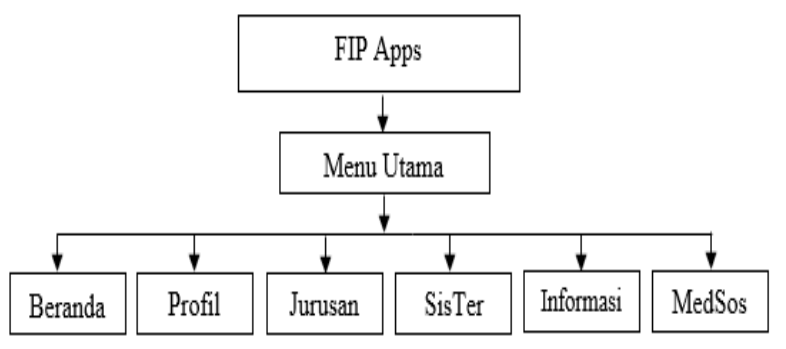

Figure 2

Navigation Structure of Android-Based Information System FIP UNNES

One of the things before developing an Android application that must be done is to design a flowchart as a media program flowchart. Flowchart is a complete depiction of the program related to the sequence of processes in it so that the flow of the program from start to finish can be clearly described [13]. Flowchart contains symbols that indicate activity and data flow in the program as the execution process. Here flowchart of development system the Android-based information at the Faculty of Education (Figure 3).

\section{Construction (Code $\&$ Test)}

After the design, it is translated into a software program in the form of an android application. Making this Android application using Thinkable Classic Software, CorelDraw X7, Adobe Photoshop CS6, and others, and then the application is ready to be tested.

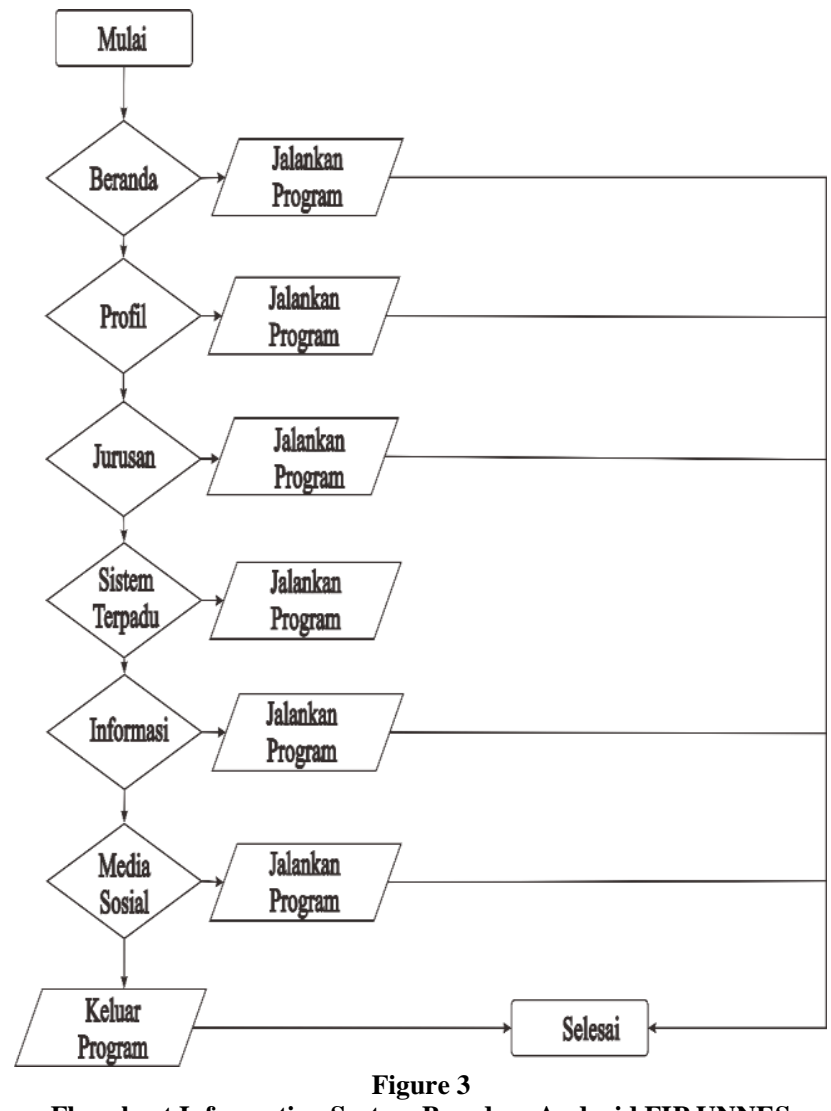

Flowchart Information System Based on Android FIP UNNES

\section{E. Deployment (Delivery, Support, Feedback)}

Stages after the software program in the form of an Android application is the application to users, both faculty, university, and general level. This will be seen from the results of feedback from the use of Androidbased information systems. In addition, specific applications will be tested for eligibility for widespread use. In addition, maintenance and repairs are carried out.

\section{TEST SUBJECT}

The application trial is intended to obtain a feasibility measurement based on ISO 25010 standards by 2 media experts.

\section{DATA COLLECTION TECHNIQUE}

Data collection techniques in this study used observation, interviews, and questionnaires. The instruments used in this study were interview guides, documentation, and expert validation sheets. Observations were made by direct observation of the media information at the Faculty of Education UNNES. The form of observation carried out aims to obtain preliminary data regarding the dissemination of information, such as: the media used, infrastructure, as well as obstacles / constraints so far.

Interviews were conducted by conducting communication between researchers and speakers to obtain data or information [14]. This technique aims to find out initial information about problems in the technical information media at the Faculty of Education UNNES. Questionnaires are data collection techniques for giving questions or written statements both open and closed to respondents to be answered. Questionnaires are used for validation testing by experts. 


\section{DATA ANALYSIS TECHNIQUES}

Data in the study of this will be analyzed by descriptive quantitative and descriptive qualitative. Qualitative data in the form of development procedures, criticisms and suggestions from the validator which is a reference for product improvement. While technical analysis of the data of quantitative used to process the data in the form of numbers into the form of descriptive percentage. Data analysis techniques used in this study include, this research is using the technique of analysis to measure the level of eligibility of products:

$\mathrm{P}=\frac{\sum n}{\sum N} x 100 \%$

Description:

$\mathrm{P}=$ percentage of application eligibility

$\sum \mathrm{n}=$ total score of respondents' evaluation aspects

$\Sigma \mathrm{N}=$ number of cases or the number of score maximum ratings

Conversion of data quantitative to qualitative to the test data feasibility media are presented in the Table 1 below.

Table 1

Converting Data Criteria Feasibility of Media

\begin{tabular}{|c|c|}
\hline Percentage of Rating & Criteria \\
\hline $76-100 \%$ & Very decent \\
\hline $51-75 \%$ & Worthy \\
\hline $26-50 \%$ & Inadequate \\
\hline $0-25 \%$ & Not feasible \\
\hline
\end{tabular}

III. RESULTS AND DISCUSSION

The development of Android-based information systems at the Faculty of Education UNNES is one form of efforts to improve the quality of public services to increase the reach of public information that can be accessed by internet users around the world. This is expected to encourage the success and progress of FIP as part of higher education institutions.

\section{A. Results of the Development of Android-Based Information Systems}

1. Communication

a. Functional Requirements Analysis

Through a brief observation that the information media owned by the Faculty of Education through the experience and work of the FIP IT and Public Relations group shows only based on websites and social media, namely Facebook, Instagram, and YouTube. The development of internet and android technology is what must be optimized to integrate all information media belonging to the Faculty of Education. This analysis includes the concept of information that is the source of data for display in Android-based information systems at the Faculty of Education, including: (1) home page; (2) profile; (3) department; (4) integrated system; (5) announcement; and (6) social media.

b. Analysis of Non-Functional Needs

While non-functional includes hardware (hardware) and software (software). In the research to be carried out, the development of Android-based information systems uses:

- Software: Thinkable Classic, WordPress, Corel Draw X5, Adobe Audition 1.5, and Adobe Premiere Pro CS6.

- Hardware: PC / Laptop with specifications: minimum RAM $4096 \mathrm{Mb}$, Intel Core i3 processor, and Windows 10 Pro-64-bit operating system. Smartphone with specifications; Android version 5.0.3, mt6752 processor $(8$ core $1.7 \mathrm{GHz})$, and $2 \mathrm{~GB}$ of memory.

Feasibility Analysis: Feasibility measurements using the ISO 25010 standard consist of functional suitability, reliability, performance efficiency, usability, security, compatibility, maintainability, and portability. But researchers will limit to 4 aspects, namely: functional suitability, compatibility, usability, and performance efficiency. Planning: the following is an implementation schedule for developing an Android-based information system at the Faculty of Education, UNNES (Table 2).

Table 2

Schedule for The Development of Android-Based Information Systems FIP UNNES

\begin{tabular}{|c|c|c|c|c|c|c|c|}
\hline \multirow{2}{*}{ No } & \multirow{2}{*}{ Activity } & \multicolumn{6}{|c|}{ Month } \\
\hline & & 1 & 2 & 3 & 4 & 5 & 6 \\
\hline \multirow[t]{4}{*}{1} & Communication & & & & & & \\
\hline & Analysis of organizational conditions & & & & & & \\
\hline & User analysis & & & & & & \\
\hline & analysis of needs & & & & & & \\
\hline \multirow[t]{3}{*}{2} & Planning (Estimating, Scheduling, Tra & kin & & & & & \\
\hline & Plan project & & & & & & \\
\hline & Tracking working system & & & & & & \\
\hline \multirow[t]{4}{*}{3} & Modeling (Analysis \& Design) & & & & & & \\
\hline & $\begin{array}{l}\text { The concept of information to be } \\
\text { included in the application }\end{array}$ & & & & & & \\
\hline & Media selection & & & & & & \\
\hline & Initial design & & & & & & \\
\hline \multirow[t]{3}{*}{4} & Construction (Code \& Test) & & & & & & \\
\hline & Making an android application & & & & & & \\
\hline & Testing & & & & & & \\
\hline \multirow[t]{4}{*}{5} & Deployment (Delivery, Support, Feedb & & & & & & \\
\hline & Internal distribution of faculties & & & & & & \\
\hline & $\begin{array}{l}\text { Distribution at the university and } \\
\text { general level }\end{array}$ & & & & & & \\
\hline & Maintenance & & & & & & \\
\hline
\end{tabular}

2. $\quad$ Modelling (Analysis \& Design)

a. Format Selection

The format of the Android-based information system in the Faculty of Education is: (1) media, there are six main menu, namely: Home, Profile, Programs, integrated system, Information, and Social Media; (2) the information displayed is in the form of text that can be scrolled vertically, images and videos; and (3) the application image icon is short for the Faculty of Education, namely: FIP.

b. Display Design

The following are some of the results of the design display application "FIP Apps" (Figure 4). 


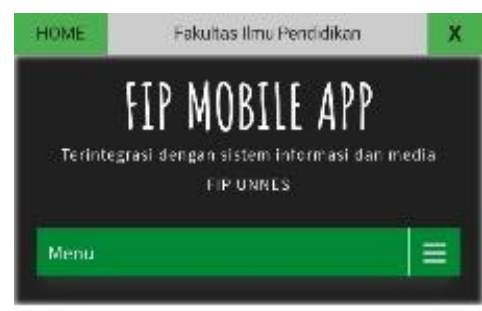

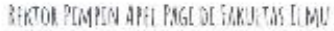
PeNaCiKan

2.3 SFPTFN'PF 2 ח19 BRII.A

Senin (23);i) bertemsacdihalaman depan

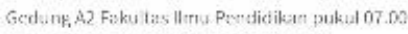
WIB, Rektor UNNES iUn versitas Negeri Semarang) Prof. Dr. Tastur Rokhman, M.Ilum tremimpir kegeja an apel sugi. Ancl ini merupekan salal satu bertuk upaya pendis pl nan kerja bag selunus dosen $[. .$. Reved ron: ?

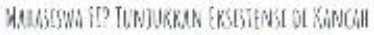

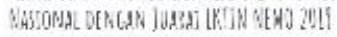
23 SERTEMBER 2019 Bevia
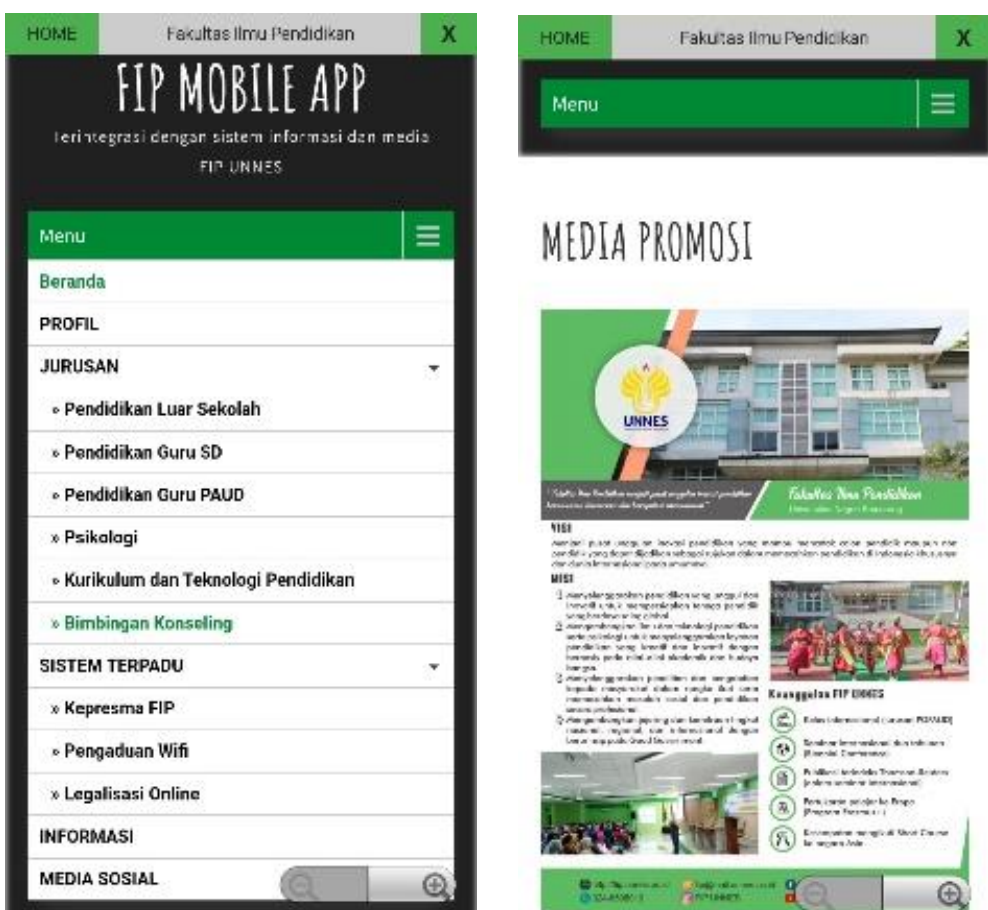

MEDIA PROMOSI

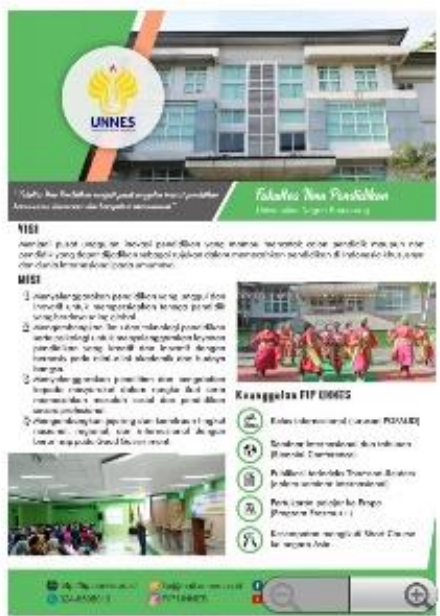

Figure 4

Display Information System Based on Android UNNES
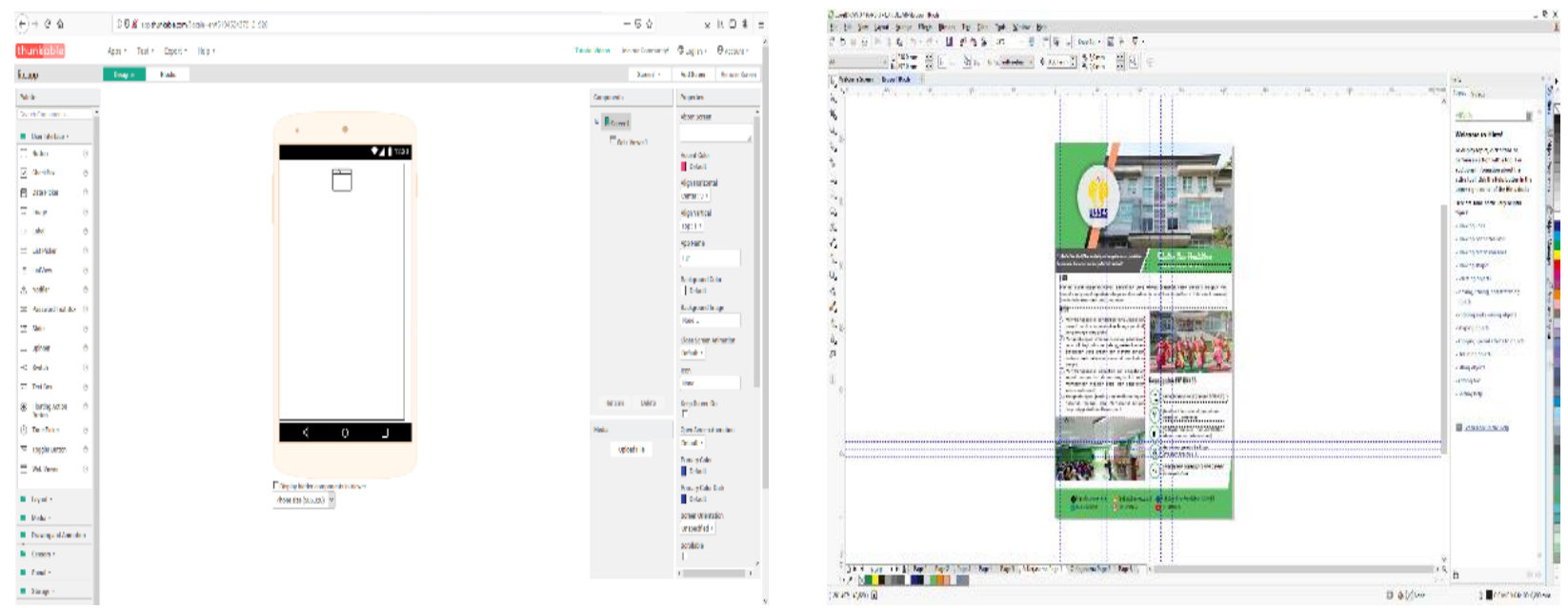

Figure 5

The Design Process in Corel Draw X7

\section{Construction}

This construction phase includes making applications using Thinkable Classic, WordPress, and CorelDraw X7. The development process in Thinkable Classic does not need to write the syntax of programming code but block programming like MIT App Inventor. WordPress in making this application works to make the pages in a website-based application (Figure 5).

\section{Deployment}

After the application is tested the validation reaches the feasibility value, the application can be distributed to users in general through the website and social media of the Faculty of Education.

\section{B. Feasibility of Information Systems Based on Android Faculty of Education}

Application products developed by the authors received criticism and suggestions from the IT and Public Relations FIP UNNES group. After repairing, an application due diligence is conducted by the expert concerned. The feasibility test of the Android-based information system aims to find out the level of appropriateness of the media before being trialed to users in general.

The appropriateness test (validation) is carried out by an expert as a validator using a questionnaire assessment sheet. After being tested for eligibility, then it is declared feasible by the validator. Then the product revision process is carried out in accordance with aspects that are considered lacking.

The assessment results are in the form of quantitative data obtained from each question item from the questionnaire used for the media expert's assessment 
of the product with criticisms and suggestions for improvement. The following is the media expert judgment data which can be seen in the following Table 3.

Table 3

The Media Expert Judgment

\begin{tabular}{|c|c|c|c|c|}
\hline \multirow[t]{2}{*}{ No } & \multirow[t]{2}{*}{ Assessment Aspects } & \multicolumn{2}{|c|}{$\begin{array}{l}\text { Expert } \\
\text { Score }\end{array}$} & \multirow[t]{2}{*}{ Total } \\
\hline & & 1 & 2 & \\
\hline \multirow[t]{4}{*}{1} & \multicolumn{4}{|l|}{ Functional Suitability Dimensions } \\
\hline & $\begin{array}{l}\text { Information or data on the application } \\
\text { is complete }\end{array}$ & 4 & 4 & 8 \\
\hline & $\begin{array}{l}\text { Menu, buttons, or navigation on the } \\
\text { application can be functioned properly }\end{array}$ & 3 & 4 & 7 \\
\hline & $\begin{array}{l}\text { Data and information displayed on the } \\
\text { application according to user needs }\end{array}$ & 3 & 4 & 7 \\
\hline \multirow[t]{3}{*}{2} & \multicolumn{4}{|l|}{ Dimensions Combability } \\
\hline & $\begin{array}{l}\text { The application can be used in various } \\
\text { versions of Android }\end{array}$ & 3 & 3 & 6 \\
\hline & $\begin{array}{l}\text { The application is able to store data } \\
\text { and information }\end{array}$ & 2 & 3 & 5 \\
\hline \multirow[t]{7}{*}{3} & \multicolumn{4}{|l|}{ Dimension Usability } \\
\hline & $\begin{array}{l}\text { How to use the application easy to } \\
\text { remember }\end{array}$ & 4 & 4 & 8 \\
\hline & $\begin{array}{l}\text { How to use the application easy to } \\
\text { learn }\end{array}$ & 3 & 4 & 7 \\
\hline & The application is easy to run & 4 & 4 & 8 \\
\hline & $\begin{array}{l}\text { The application display is easy to } \\
\text { understand }\end{array}$ & 3 & 4 & 7 \\
\hline & $\begin{array}{l}\text { Applications can be operated by } \\
\text { several users (different devices) at the } \\
\text { same time }\end{array}$ & 3 & 3 & 6 \\
\hline & $\begin{array}{l}\text { There is a notification if there is an } \\
\text { error in the operation of the application }\end{array}$ & 3 & 4 & 7 \\
\hline \multirow[t]{3}{*}{4} & \multicolumn{4}{|l|}{ Dimension Performance Efficiency } \\
\hline & $\begin{array}{l}\text { The application provides responses in } \\
\text { the form of data and information } \\
\text { quickly }\end{array}$ & 4 & 4 & 8 \\
\hline & $\begin{array}{l}\text { When the application is busy being } \\
\text { used is not down and remains } \\
\text { accessible }\end{array}$ & 3 & 4 & 7 \\
\hline & $\begin{array}{l}\text { Total } \\
\end{array}$ & 42 & 49 & 91 \\
\hline
\end{tabular}

Based on Table 3 shows that the overall results of validation from media experts are $87,5 \%$ and are included in the very feasible category. After assessed feasibility media then be repaired and ready media piloted in use in general. In addition, this Android-based information system has several advantages and disadvantages. This was obtained from the statements of media experts and users through questionnaires and interviews. The advantages of this information media, namely: (1) media products in the form of an android package (APK) with a size of less than $5 \mathrm{MB}$, (2) presentation of information content in a systematic application and easy to operate, and (3) media is interactive so it is expected to be interesting the user. In addition to strengths, this media has several disadvantages, namely: the need to connect internet data to access content in the application.

\section{ACKNOWLEDGMENTS}

Praise and thank the authors give to God who has given favors and blessings to all of us so that the scientific article entitled "Development of Android-Based Information Systems Faculty of Education" we can finish. The author thanks all parties involved in the authorship of this scientific article. In particular, we present it to the IT and Public Relations Team of the Faculty of Education, media experts, and users in testing information systems.

\section{REFERENCES}

[1] D. H. Jayani, "Indonesia Peringkat Kelima Dunia dalam Jumlah Pengguna Internet", databoks, 11 September 2019, [Online]. Available: https://databoks.katadata.co.id/datapublish/2019/09/11/ind onesia-peringkat-kelima-dunia-dalam-jumlah-penggunainternet [Accessed: 23 August 2019].

[2] APJII, "Penetrasi \& Perilaku Pengguna Internet Indonesia 2017", KOMINFO. [Online]. Available: https://web.kominfo.go.id/sites/default/files/Laporan\%20S urvei\%20APJII_2017_v1.3.pdf. [Accessed: 2 August 2019].

[3] APJII, "Hasil Survei Penetrasi dan Perilaku Pengguna Internet Indonesia 2018, Asosiasi Penyelenggara Jasa Internet Indonesia. [Online]. Available: https://apjii.or.id/survei. [Accessed: 20 August 2019].

[4] nks, "Jumlah Pengguna Smartphone di Seluruh Dunia dari 2014-2020", Teknologi.id, 16 March 2018. [Online]. Available: https://teknologi.id/insight/jumlah-penggunasmartphone-di-seluruh-dunia-dari-2014-2020/. [Accessed: 12 August 2019].

[5] I. F.Setiawan, Astuti,and D.M.Khairina,"Rancang Bangun Game Edukasi Berbasis Android Tebak Lagu Nusantara: Senara", Jurnal Informatika Mulawarman,Vol.9,no.2, pp.24-30, Juny 2014.

[6] K. S. Permana,"Ketika Pengguna Internet dan Smartphone Terus Meningkat, Android Dominasi Pasar Indonesia dan Dunia", TribunJabar.id, 24 Januariy 2019, [Online]. Available: http://jabar.tribunnews.com/2019/01/24/ketikapengguna-internet-dan-smartphone-terus-meningkatandroid-dominasi-pasar-indonesia-dan-dunia/. [Accessed: 28 April 2019].

[7] H. P. Seto and M.B. R. Wijaya, "Peningkatan Pemahaman Materi Pembelajaran Sistem EFI (Electronic Fuel Injection) Menggunakan Media Elektronik Berbasis Android", Jurnal Pendidikan Teknik Mesin, Vol.16, No.2, pp.76-79, December 2016.

[8] S. Aswati, N. Mulyani, Y. Siagian, and A.Z. Syah, "Peranan Sistem Informasi dalam Perguruan Tinggi", Jurnal Teknologi dan Sistem Informasi, Vol.1, No.2, pp.79-86, March 2015.

[9] Sugiyono, Metode Penelitian Pendidikan, Bandung: Alfabeta, 2015.

[10] F. Tanzil, "Waterfall Model", BINA NUSANTARA, 21 December 2019, [Online]. Available: http://socs.binus.ac.id/2018/12/21/waterfall-model/. [Accessed: 29 Mei 2019].

[11] Y. I.Chandra, "Aplikasi Pembelajaran Angka, Bentuk, Huruf dan Warna Untuk Anak-Anak Menggunakan Metode Computer Assisted Instruction (CAI) Berbasis Android", Jurnal Ilmiah Komputasi, Vol.15, No.1, pp.713, Juny 2016.

[12] N. Azizah, B. B. Butar, and I. T. Wahyuni,"Animasi Interaktif Pengenalan Dasar Bahasa Inggris pada TK AnNuruddin Depok", Innovative Creative and Information Technology, Vol.4, No.1, pp.29-40, February 2018.

[13] D. Darmawan, Mobile Learning Sebuah Aplikasi Teknologi Pembelajaran. 1th Ed. Jakarta: Rajawali Pers, 2016.

[14] Wahyudin, Metodologi Penelitian, Semarang: Unnes Press, 2015. 